\title{
THE ROLE OF LOGISTIC FOR POLISH ECONOMY DEVELOPMENT
}

\author{
Bogdan Klepacki, Full Professor ${ }^{1}$ \\ Faculty of Economic Science, Warsaw University of Life Science - SGGW
}

\begin{abstract}
One of the most important sectors currently determining the economic situation of countries, regions, including rural areas and enterprises is logistics. The study presents the directions of the impact of logistics on the economy and changes in equipping Poland with more important elements of the logistics infrastructure, namely transport and storage infrastructure. The place of the logistics sector in the national economy was presented, measured by the share of transport, storage, information and communication, against the background of industry, trade and construction, in the creation of the Net Domestic Product. The logistic competitive position of Poland against the background of neighbouring countries was also determined. It was found that it is high, and logistics can be an important factor in the development of the country. The development of logistics at the Faculty of Economic Sciences at SGGW was also presented.
\end{abstract}

Keywords: logistics, transport infrastructure, storage, Logistic Performance Index (LPI)

JEL codes: O11, O18

\section{INTRODUCTION}

One of the most dynamically developing segments of the national economy is currently logistics. The scale of human travel, freight transport, the flow of financial capital and information is increasing. This requires the development of point and continuous infrastructure elements. This is of great importance for the creation of open logistic chains and lowering their operating costs. It contributes to the development of entire countries, including rural areas.

The aim of the study was to determine the directions of impact of logistics on the Polish economy, changes in the equipment in the more important elements of logistics infrastructure, as well as its participation in the creation of Gross Domestic Product and determining the competitive position of the country against the background of neighbouring countries.
The research used materials from the reports of the Statistics Poland, data from Eurostat, the World Bank and research results available in specialist literature. Analysis uses both a vertical dynamic (changes over time) and horizontal (international comparisons) methods.

\section{REASONS FOR THE DEVELOPMENT OF LOGISTICS}

Logistics is usually defined as a method of supply chain management, which includes planning, implementation and control of efficient, effective flow of raw materials and materials for production, finished products as well as transmission of relevant information from the point of origin to the point of consumption in order to meet customer requirements. It is also referred to as managing the processes of moving goods and people

${ }^{1}$ Corresponding author: Nowoursynowska 166, 02-787 Warsaw, Poland, bogdan_klepacki@sggw.pl, +48 604466569 
and activities supporting these processes in the systems in which they occur (Fertsch, 2006). Its main goal is to minimize the cost of flow of products in the supply chain, while increasing the profit in each company while maintaining the expected level of customer service.

Logistics as an element of human activity has been functioning since ancient times. However, it had a mainly local dimension. Today, there are many reasons for this phenomenon, but the following can be mentioned as the most important (Klepacki, 2014, 2018):

- reserves of cost savings in the field of techniques and production technology have already been largely exhausted, they can be more obtained as a result of optimization of transport, forwarding, storage, or streamlining of flows;

- offer for customers is constantly expanded, both as to the range of products and the consideration of customer requirements;

- manufacturers and retailers want the shortest and the least products store;

- traditional, low-efficient distribution systems have become too expensive, businesses cannot afford to use not full means of transport;

- IT development has enabled optimization of logistic operations in technical, organizational and economic terms;

- the importance of precision in the delivery of raw materials, semi-finished products and final products increases; in mass or standard production, the 'just in time' technique is widely used, and in the individualized production 'just in sequence';

- globalization of enterprises activities takes place, which is connected with the increasing flow of capital, goods, technologies and information on the scale of the entire planet.

\section{DIRECTIONS OF LOGISTICS IMPACT ON THE NATIONAL ECONOMY}

The impact of logistics on the economy can be considered from different points of view. An attempt to systematize this impact is presented in Table 1.

The presented summary does not exhaust the whole issue, but gives an overview of the scale and multidirectional impact of logistics on the state and directions of changes in the economy and society.

\section{IMPORTANCE OF TRANSPORT INFRASTRUCTURE IN SOCIO-ECONOMIC DEVELOPMENT}

Transport infrastructure is the roads of all branches, transport points, which include airports, ports, etc. and a number of auxiliary devices. Transport infrastructure creates convenient conditions for moving cargoes and transporting people. The most important functions fulfilled by the transport system are consumption, production and integration (Rydzkowski and Wojewódzka- Król, 1997).

The largest increase in demand for transport infrastructure was recorded in the period of accelerated industrialization. Also today, there is a strong correlation between economic growth and the development of transport infrastructure, which results, among others, from globalization processes, opening of foreign markets, liberalization of trade between countries from different continents. The main reason for the increase in passenger transport is the need to commute to work, as well as the improvement of household incomes.

Ensuring access to transport infrastructure and the proper level of its capacity facilitates the so-called diffusion of economic growth between regions (from regions better to those more slowly developing, especially from agglomerations to rural and agricultural areas) (Zimny, 2016).

The construction of new infrastructure elements has both advantages and disadvantages. The advantages include fast and safe traveling, overcoming long distances. The area with developed infrastructure is attractive for investors and tourists. New jobs are created and residents have the opportunity to work outside their place of residence. Infrastructure, however, may have a negative impact on the natural environment. Road construction is connected with the necessity of designating large areas under it, soils lose their production usefulness and the areas degrade. Dust from means of transport is a threat, irreversible changes occur in fauna and flora. Animals lose their natural living conditions due to felling of forests, plant complexes are damaged. The shape of the terrain, landscape and water conditions change, they take place. In the social sphere, for example roadside accidents are a negative effect (Chrabąszcz, 2012). 
Table 1. Important directions of the impact of logistics on socio-economic development

\begin{tabular}{|c|c|c|}
\hline No & Directions of impact & More important impact \\
\hline I & economical & $\begin{array}{l}\text { GDP production } \\
\text { place of employment } \\
\text { source of income of the population } \\
\text { source of state income } \\
\text { source of income of local governments } \\
\text { increasing investors' interest } \\
\text { modern solutions in management and technology } \\
\text { inducing development of other sectors of the economy }\end{array}$ \\
\hline II & technical & $\begin{array}{l}\text { technical and technological similarity on a global scale } \\
\text { standardization of packaging and means of transport } \\
\text { development of specialized means of transport } \\
\text { development of IT systems } \\
\text { innovations in warehouse construction and transport }\end{array}$ \\
\hline III & social & $\begin{array}{l}\text { stimulus for building infrastructure serving the society } \\
\text { improving people-to-people contacts in macroeconomic terms } \\
\text { point increase in congestion } \\
\text { separation of hitherto compact local societies }\end{array}$ \\
\hline IV & political & $\begin{array}{l}\text { increased strength and position of the country } \\
\text { political stabilization }\end{array}$ \\
\hline V & legal & $\begin{array}{l}\text { unification of legal regulations } \\
\text { increase transport safety } \\
\text { reducing international crime }\end{array}$ \\
\hline VI & environmental & $\begin{array}{l}\text { modernization of communication routes, including environmental requirements } \\
\text { reducing the area of forests and agricultural land } \\
\text { contamination by exhaust fumes }\end{array}$ \\
\hline VII & military & $\begin{array}{l}\text { increasing the mobility of military units } \\
\text { improvement of communication and transport of people, goods and means of defense } \\
\text { development of communication systems between individuals } \\
\text { preparation of civil solutions for defense purposes }\end{array}$ \\
\hline VIII & academically & $\begin{array}{l}\text { a new area of education } \\
\text { a large, undisclosed research area }\end{array}$ \\
\hline
\end{tabular}

Source: own study.

In Poland, according to Statistics Poland (Local Data Bank) data, in 2016 there were 420.2 thousand $\mathrm{km}$ of public roads. Most were municipal roads $-58.8 \%$, district ones accounted for $29.7 \%$, voivodship $6.9 \%$, and domestic $4.6 \%$. The saturation of motorways is often recognized as an element of modern transport infrastructure. In terms of their density compared to EU countries, Poland is weak. In 2016 , there were $5.2 \mathrm{~km}$ of highways per 1,000 $\mathrm{km}^{2}$, while in the Netherlands, for example, $66 \mathrm{~km}$ (13 times more) and Luxembourg (58 km) (Eurostat, 2018).

Generally, it can be concluded that in terms of transport infrastructure, Poland is less advanced than Western European countries, but there is a decisive progress and after completing planned road and rail investments it will not be a barrier limiting the development of logistics and other economic activities. 


\section{CHANGES IN THE WAREHOUSE MANAGEMENT}

Warehousing is the second most important element of logistics. In Poland, the warehouse market is dynamically developing both on the demand and supply sides. At the end of 2017, the area of almost 13.4 million $\mathrm{m}^{2}$ was available, while in 2007 there were 4.7 million $\mathrm{m}^{2}$ (Mierzwiak and Klepacki, 2018). Last year, the area increased by over $14 \%$, and the warehouse market increased by over one million $\mathrm{m}^{2}$.

The demand side is also showing an upward trend, e.g. in 2015 it increased by over 5\% (JLL, 2016). This is due to the good economic situation, the growing demand for space from the e-commerce sector and the increase in the outsourcing of logistic services by retail chains or production companies. The most modern warehouses are rented by logistics operators and retail chains. In the regional cross-section, the highest demand for warehouse space occurs in central Poland, in the Warsaw area, in Upper Silesia, in Poznań and in Wrocław. Investors locate warehouse space at the junctions of highways and expressways. It can be stated that tenants who are opting for the local market choose the central one, while on the in- ternational scale - the southern part of the country (Fechner and Szyszka, 2014).

Operated stores have a different degree of technological advancement. Modern warehouses play an especially important role, by which we mean surfaces in buildings with a storage height of at least $9 \mathrm{~m}$, minimum one gate per $1,000 \mathrm{~m}^{2}$, free floor, minimum 5 tonnes $/ \mathrm{m}^{2}$ durability, fire protection system in the form of sprinklers and smoke dampers, and 5-8\% of office space [Logistics ... 2009]. Modern warehouse space in mid-end of 2017 in Poland covered almost 12 million $\mathrm{m}^{2}$ (Fig. 1).

In terms of modern warehouse space, there has been significant progress. Over a period of 16 years, it has increased over 10 times. This means that the attractiveness of Poland as a location for investments related to logistics has been increasing.

\section{ECONOMIC IMPORTANCE OF LOGISTICS IN POLAND'S NATIONAL ECONOMY}

The importance of individual sectors in the national economy can be measured, among others by their contribution to the creation of Gross Domestic Prod-

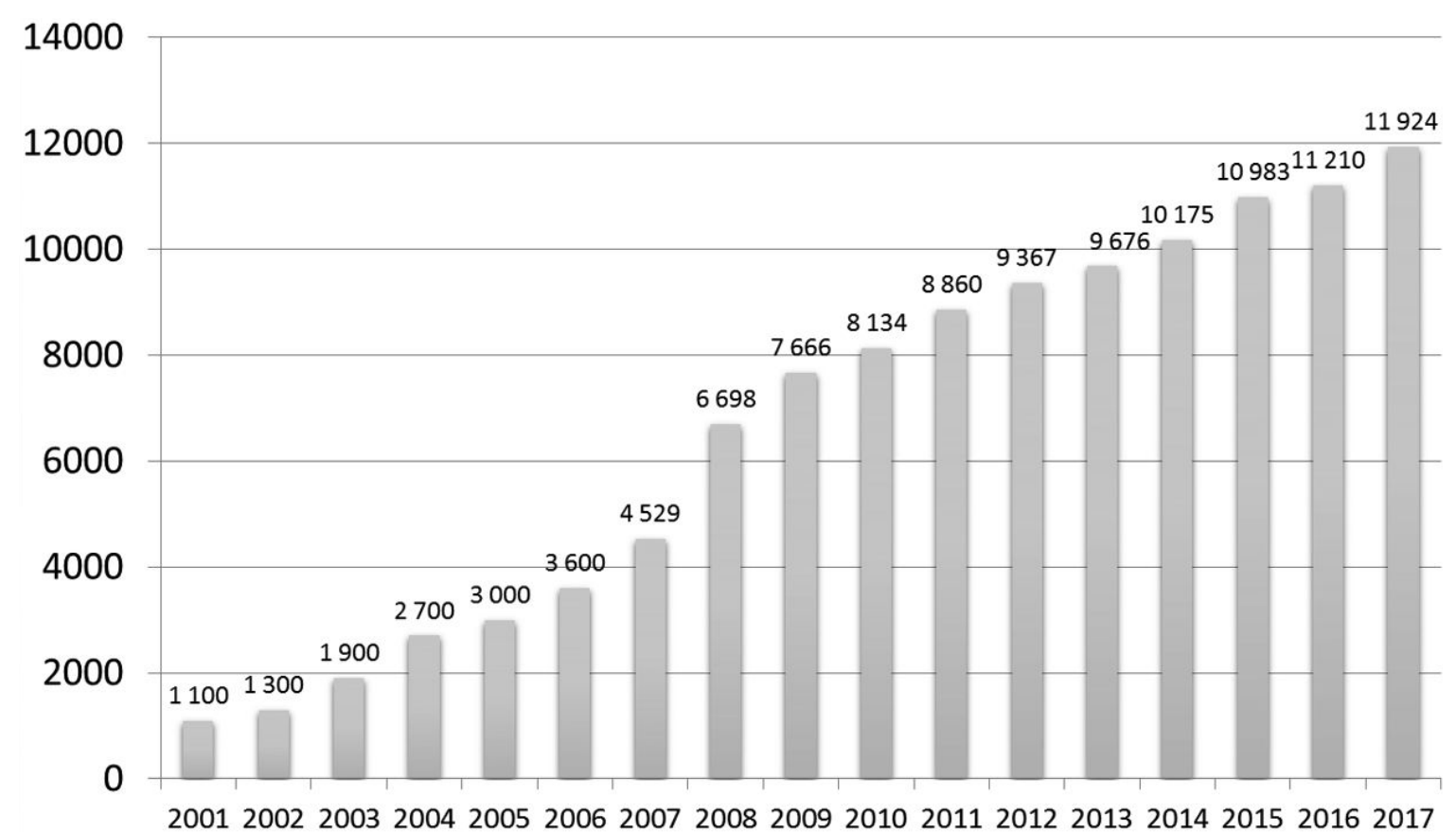

Figure 1. Area of modern warehouses in years 2001-2017 (thousand $\mathrm{m}^{2}$ )

Source: Fechner and Szyszka (2009, 2010); GUS (2006, 2010, 2016). 
uct (GDP). In 2015, the share in the GDP structure of selected sectors was as follows ${ }^{2}$ :

- industry $-23.5 \%$;

- car sales and repair $-15.4 \%$;

- building industry $-6.3 \%$;

- transport and storage economy $-5.8 \%$;

- IT and communication - 3.6\%;

- water supply, sewage and waste collection $-1.3 \%$. Including strictly logistic sectors in logistics (transport and storage, information and communication, water management and waste), we state that $10.7 \%$ of GDP was generated in them, however, logistics is not fully included in the statistics. It constitutes a significant part of commercial and industrial activities, etc. By adding to the above-mentioned value of trade and repair of cars, we obtain over $25 \%$. Therefore, it can be stated that logistic and related activities, without industry, bring the national economy at least one quarter of GDP.

For general employment in the country amounting to 15.4 million people in transport and storage economy in 2015, 5.3\% was employed, and in the information and communication a further $2.2 \%$. Logistics also involved $15.5 \%$ of total fixed assets. GDP per employee in transport and storage was $110.5 \%$, and in information and communication,
$163.8 \%$ of the average value in the entire national economy.

\section{COMPETITIVE POSITION OF POLISH LOGISTICS IN RELATION TO SELECTED NEIGHBOURING COUNTRIES}

The level of competitiveness of logistic enterprises can be measured in many ways. Logistic Performance Index (LPI) is the most widespread. It is calculated for 163 countries $^{3}$ and determined taking into account six characteristics, namely:

- efficiency of the clearance process by order control agencies, including customs;

- quality of trade and transport related infrastructure (e.g. ports, traction, roads, IT),

- easy of arranging competitively priced shipments;

- competence and quality of logistic services;

- ability to track and trace consignments;

- timeless of shipments in reaching destination within a schedule or expected delivery time.

Poland is relatively well prepared to provide logistics services (Table 2). Although it has a worse rating than Germany, which is a world leader, however, on a regional scale it ranks at a similar level to its neighbours. Compared to the situation in 2007,

Table 2. Competitive position of Polish logistics against the background of selected Central European countries in 2007-2016

\begin{tabular}{|l|c|c|c|c|c|c|}
\hline \multirow{2}{*}{ Country } & \multicolumn{5}{|c|}{ LPI } & \multirow{2}{*}{ Place in the world ranking in 2016 } \\
\cline { 2 - 6 } & 2007 & 2010 & 2012 & 2014 & 2016 & 33 \\
\hline Poland & 3.04 & 3.44 & 3.43 & 3.49 & 3.43 & 1 \\
\hline Germany & 4.10 & 4.11 & 4.03 & 4.12 & 4.23 & 26 \\
\hline Czech Republic & 3.13 & 3.51 & 3.14 & 3.49 & 3.67 & 41 \\
\hline Slovakia & 2.92 & 3.24 & 3.03 & 3.25 & 3.34 & 80 \\
\hline Ukraine & 2.55 & 2.57 & 2.85 & 2.98 & 2.74 & 29 \\
\hline Lithuania & 2.78 & 3.13 & 2.95 & 3.18 & 3.63 & 31 \\
\hline Hungary & 3.15 & 2.99 & 3.17 & 3.46 & 3.43 & 43 \\
\hline Latvia & 3.02 & 3.25 & 2.78 & 3.40 & 3.33 & 2 \\
\hline
\end{tabular}

Source: Arvis et al. (2016).

\footnotetext{
${ }^{2}$ Own calculations based on: Statistical Yearbook of Poland 2017, pp. 699-700.

${ }^{3}$ So far LPI has been calculated for years 2007, 2010, 2012, 2014 and 2016.
} 
all areas have made good progress, and Poland has moved from 40 to 33 in the world ranking.

\section{PLACE OF THE FACULTY OF ECONOMIC SCIENCES WULS-SGGW IN THE DEVELOPMENT OF LOGISTICS}

Observation of the situation in the national economy and the labour market prompted the Faculty authorities to meet the challenges and launch the 'logistics' direction. On 18 December 2006, the Senate of the Warsaw University of Life Sciences WULS-SGGW appointed him as a first-cycle program (the first in public non-military universities in Poland), in 2012 the second-degree studies were created. In total, in the period leading the logistics, that is, from 2007 to the present, the university graduated 589 on full-time studies and 855 on part-time studies, witch totally give us a number of 1,444 graduates.

The changes also concerned the organizational structure. In 2008 was created Division of Economics of Production and Logistics. In 2012 Division of Economics and Engineering of Logistics was founded, and in 2017 was appointed the Department of Logistics, in which currently is employed eleven people and three $\mathrm{PhD}$ students perform the dissertation.

The research and development area of the Department includes, among others, defining the directions of logistics development and its impact on the economics and organization of enterprises, with particular emphasis on production processes, transport and storage of agricultural production, optimization of logistics business costs, storage and transport of dangerous goods, air and service logistics. Other areas are determining the place of logistics in the economic development of the country and the region, shaping the theory and practice of logistics used in agribusiness enterprises, shaping effective logistics chains in agribusiness, information systems and IT in domestic and international logistics.

\section{CONCLUSIONS}

1. Poland is an important place to provide logistics services, including due to its central location in Europe, which is increasingly making internation- al exchanges. After joining the European Union, many infrastructural investments were made in Poland, which made it possible to achieve a level of logistics development comparable to that in other EU countries. This means that Polish logistics will not be a limitation, but rather an important factor for the development of the country at the macroeconomic and local level.

2. Polish logistics companies are growing rapidly, the area of modern warehouses is growing, they are improving their offer, hence their international competitiveness is growing. Logistics is becoming a Polish specialty that is increasingly shaping the level of GDP and the state of the national economy.

3. The Faculty of Economic Sciences WULS-SGGW adjusts its didactic offer as well as conducts scientific research in accordance with the prospective development directions of the Polish and world economy. It also develops contacts with logistics companies that are important on the Polish and global market.

\section{REFERENCES}

1. Arvis, J.F., Mustra, M.A., Panzer, J., Ojala, L., Naula, T. (2007). Connecting to Competence. Trade Logistics in the Global Economy. The Logistics Performance Index and Its Indicators. The International Bank for Reconstruction and Development. The World Bank, Washington.

2. Chrabąszcz, K. (2012). Cechy regionalne a rozwój krajowej infrastruktury drogowej na przykładzie autostrady A4 [Dictionary of logistics terminology Regional features and the development of national road infrastructure on the example of the A4 motorway]. Zeszyty Naukowe Małopolskiej Szkoły Ekonomicznej w Tarnowie, 20 (1). Retrieved from: http://zn.mwse.edu.pl/ebooki/20/39-47.pdf [Accessed 20.06.2017].

3. Eurostat (2018). Length of motorways and e-roads [road_if_motorwa]. Retrieved from: http://appsso. eurostat.ec.europa.eu/nui/show.do?dataset=road_if motorwa\&lan $=$ en [Accessed 21.06.2017].

4. Fechner, I., Szyszka, G. (ed.) (2009). Logistyka w Polsce. Raport 2007 [Logistics in Poland. Report 2007]. Biblioteka Logistyka. Instytut Logistyki i Magazynowania, Poznań 2009. 
5. Fechner, I., Szyszka, G. (ed.) (2010). Logistyka w Polsce. Raport 2009 [Logistics in Poland. Report 2009]. Biblioteka Logistyka. Instytut Logistyki i Magazynowania, Poznań.

6. Fechner, I., Szyszka, G. (ed.) (2014). Logistyka w Polsce. Raport 2013. Biblioteka Logistyka, Poznań.

7. Fertsch, M. (ed.) (2006). Słownik terminologii logistycznej [Dictionary of logistic terminology]. Instytut Logistyki i Magazynowania, Poznań.

8. GUS (2006). Rocznik Statystyczny Rzeczypospolitej Polskiej 2006 [Statistical Yearbook of Poland 2006]. Dział Wydawnictw Statystycznych, Warszawa.

9. GUS (2010). Rocznik Statystyczny Rzeczypospolitej Polskiej 2010 [Statistical Yearbook of Poland 2010]. Dział Wydawnictw Statystycznych, Warszawa.

10. GUS (2016). Rocznik Statystyczny Rzeczypospolitej Polskiej 2016 [Statistical Yearbook of Poland 2016]. Dział Wydawnictw Statystycznych, Warszawa.

11. JLL (2016). Rynek nieruchomości magazynowych w Polsce w 2015 r. [Warehouse market in Poland in 2015]. Retrieved from: bpcc.org.pl/uploads/.../Rynek nieruchomo_ci_magazynowych_w_Polsce_2015.pdf.

12. Klepacki, B. (2014). Concept and importance of agrologistics for development of agribusiness.
In: Proceedings of Carpathian Logistics Congress (CLC), Cracow, 09-11.12.2013. VSB Tech University Ostrava, Technical University Kosice. TANGER, pp. 14-17.

13. Klepacki, B. (2018). Directions of Development and the Role of Logistics in polish Economy. In: Proceedings of 19th International Scientific Conference "Economic Science for Rural Development", Jelgava, 09-11.05.2018.

14. Mierzwiak, B., Klepacki, B. (2018). Rekordowe wyniki rynku magazynowego w Polsce - początek czy koniec dynamicznego rozwoju [Record-breaking results of the warehouse market in Poland - the beginning or end of dynamic development]. In: Retail Summit, Warsaw, 13.03.2017, pp. 1-18.

15. Rydzkowski, W., Wojewódzka-Król, K. (ed). (1997). Transport. PWN, Warszawa.

16. Zimny, A. (2016). Wskaźniki rozwoju transportu w ogólnopolskich i regionalnych dokumentach strategicznych [Indicators of transport development in national and regional strategic documents]. Konińskie Studia Społeczno-Ekonomiczne, 2 (3), pp. 255-272. Retrieved from: http://ksse.pwsz.konin.edu.pl/wp-content/uploads/2017/03/KSSE-23.final_.pdf. 